Abstracta Iranica Abstracta Iranica

Revue bibliographique pour le domaine irano-aryen

Volume 23 | 2002

Comptes rendus des publications de 2000

Berlanī-hā. Andīšmandān-e ìrānī dar Berlan 1915-1930. Tehrān, Farzān, 1379, 233 p., bibliographie, index.

Yann Richard

OpenEdition

Journals

Édition électronique

URL : http://journals.openedition.org/abstractairanica/35649

DOI : $10.4000 /$ abstractairanica.35649

ISSN : 1961-960X

Éditeur :

CNRS (UMR 7528 Mondes iraniens et indiens), Éditions de l'IFRI

Édition imprimée

Date de publication : 15 mai 2002

ISSN : 0240-8910

Référence électronique

Yann Richard, « Berlanī-hā. Andīšmandān-e îrānī dar Berlan 1915-1930. Tehrān, Farzān, 1379, 233 p.,

bibliographie, index. », Abstracta Iranica [En ligne], Volume 23 | 2002, document 346, mis en ligne le 08

février 2010, consulté le 25 septembre 2020. URL : http://journals.openedition.org/abstractairanica/ 35649 ; DOI : https://doi.org/10.4000/abstractairanica.35649

Ce document a été généré automatiquement le 25 septembre 2020.

Tous droits réservés 


\title{
Berlanī-hā. Andīšmandān-e ìrānì dar Berlan 1915-1930. Tehrān, Farzān, 1379, 233 p., bibliographie, index.
}

\author{
Yann Richard
}

1 Plusieurs travaux importants en allemand et en persan concernent les activités des nationalistes iraniens à Berlin de 1915 à 1930. Le premier militant à avoir utilisé les moyens mis à sa disposition par la politique anti-anglaise du Kaiser avait rassemblé autour de la revue Kāve une compagnie de jeunes intellectuels et écrivains qui marquèrent profondément l'entrée de l'Iran dans la modernité : Qazvīnī, Jamālzāde, Pūr Dāvūd, ... Le présent livre de J.B. continue le travail qu'il avait publié précédemment sous le titre Irāniān va andīše-ye tajaddod (Les Iraniens et l'idée de modernité - Tehrān, Farzān, 1375) : il s'agit pour lui de découvrir les racines iraniennes de la modernité et de montrer, à travers les processus historiques complexes, que la modernité est à l'œuvre en Iran de manière originale, sans avoir été imposée par une colonisation, mais avec l'interaction des ingérences étrangères, des pouvoirs autoritaires et des élites ayant étudié en Europe. L'épisode de la Première Guerre mondiale est en lui-même révélateur de l'interdépendance des idées réformistes, des pressions extérieures et des réalités économiques: désormais les Iraniens doivent penser leur destin comme lié à celui des grandes puissances. Dans le livre sur les «Berlinois », après l'historique des vagues d'intellectuels iraniens installés bon gré mal gré dans la capitale allemande pendant la période choisie, l'auteur s'attarde, dans une deuxième partie, à leurs idées. A l'aide d'une excellente documentation (la revue Kāve, les correspondances et les mémoires des acteurs historiques), J.B. retrace d'abord la vie quotidienne des exilés, leurs liens avec la patrie, leurs activités politiques, intellectuelles et commerciales. Puis il montre comment, dans la République de Weimar, les courants socialistes prennent place à côté de l'idéologie patriotique : Taqī Arānī passe du nationalisme chauvin au marxisme ; la revue Peykār est fondée en 1930 par Morteḍā 'Alavī. Un chapitre rassemble les quatre revues "modernisantes » et réformatrices : la deuxième série de Kāve (1920-1922), İrānšahr (1922-27), Farangestān (1924, fondée par Mošfeq Kāẓemī), et 'Elm va honar (Berlin-Leipzig 1927, Jamālzāde). L’A. 
évoque le retour des exilés vers la patrie après 1920 et leur rôle dans la reconstruction du pays : l'Association Jeune-Iran (Anjoman-e İrān-e javān) autour de 'Alī-Akbar Siāsī (1921) et de la revue du même nom, à ne pas confondre avec la parti İrān-e now de Teymūr-Tāš. Dāvar fonde le journal Mard-e āzād en 1922, Mahmūid Afšār Āyande en 1925 et Taqī Arānī Donyā en 1930. Le destin le plus varié attende les collaborateurs de Kāve : Taqīzāde passe par la diplomatie, les ministères les plus importants, pour retourner à l'exil ; Jamālzāde s'établira à Genève... La deuxième partie du livre entreprend un tableau comparatiste entre les intellectuels iraniens, arabes et turcs sur quatre thèmes principaux liés à la modernité : la nation, la religion, la structure du pouvoir politique et l'influence européenne. Il faut rendre hommage à Behnām pour avoir réussi cette excellente synthèse, sans prétention à l'érudition, mais avec une excellente documentation de première main et une visée d'ensemble qui devrait inciter les recherches sur chacun des personnages évoqués : beaucoup sont encore largement méconnus alors que, comme Behnām le montre, ce sont les artisans de la construction de l'Iran moderne.

INDEX

Thèmes : 13.2. Afghanistan

\section{AUTEURS}

\section{YANN RICHARD}

Sorbonne Nouvelle - Paris III 